\title{
Factors Related to the Implementation of Evidenced-Based Practice (EBP) of Nursing Staffing Levels in Hospitals: A Literature Review
}

\author{
Ikar Swito $^{1}$, Andi Indahwaty Sidin ${ }^{2}$, Rini Rachmawaty ${ }^{3}$ \\ ikarswito88@gmail.com \\ ${ }^{1}$ Master of Public Health Students, Faculty Public Health, Hasanuddin University, Indonesia \\ ${ }^{2}$ Lecturer Master of Public Health, Faculty of Public Health, Hasanuddin University, Indonesia \\ ${ }^{3}$ Lecturer Master of Nursing, Faculty of Nursing, Hasanuddin University, Indonesia \\ Received: January 5, $2021 \quad$ Received in Revised: January 26, $2021 \quad$ Accepted: February 6, 2021
}

\begin{abstract}
The implementation of Evidenced-based practice (EBP) was one of the factors in increasing the quality of health services as an ideal problem-solving approach. The ability of nurses to appliance EBP was influenced by many factors, not only on individual nurses consisting by the support of unit leader and colleague. The purpose of this study was to determine the factors associated with the implementation of EBP at the care room level establishing on the support of coworkers and nursing managers. This writing used a literature review study, from several databases namely PubMed, ProQuest, Google Scholar, and ScienceDirect with a limitation of the last 5 years. 17 journals met the inclusion criteria and the results of a literature review study show: eight journals conclude that the support of colleagues and authority in changing practices affects the implementation of EBP, 13 journals concluded the role of managerial nurses affects the implementation of EBP consisting of leadership support and mentorship including the lack of knowledge and skills of nursing leaders regarding EBP. Data from the collected and identified literature study clearly showed that EBP knowledge and skills of nursing leaders related to EBP are important factors in increasing the implementation of EBP but co-worker factors can be a supporter and also an obstacle to the implementation of EBP if it is not well managed..
\end{abstract}

Keywords: Evidence-Based Practice, Nursing, Implementation, Readiness, Barriers

\section{Introduction}

Evidence-based practice is a cornerstone of nursing practice that is a means of improving the quality of patient care (American Academy of Nursing, 2016). Other research has shown a corresponding pattern of contextual differences in judgments of The World Health Organization recommends that nursing care obtained by patients is free from bias, therefore efforts to increase research and implementation of research results are very necessary (Jylhä et al., 2017). Therefore, the implementation of EBP in nursing services in Indonesia is supported by the Nursing Law which states that nursing practice must be based on scientific values.

Research conducted in Indonesia was more on the individual factors of nurses, while the managerial level was still within the scope of hospital management. In case of the research at Bukittinggi Hospital in West Sumatra concluded that hospital management support was low and nurses' expectations were rising to the awareness and motivation of EBP in nurses (Irmayanti et al., 2019). As currently known, the research related to the implementation of EBP in developed 
countries was more holistic, not only individual nurses and hospital management but is able to assess to the unit level so that this phenomenon makes the writer want to know what factors are associated with the implementation of Evidenced-based practice (EBP) nurses at the work unit level in hospital.

\section{Methods}

Literature review method is a method of collecting library data or sources among journals, books, documentation, internet and literature that are relevant to the topics raised then reading and processing the writing material (Nursalam, 2015).

The data search process was carried out using the electronic database PubMed, Google Scholar, ProQuest, and ScienceDirect. The inclusion criteria in this literature are English language journals with the last 5 years of publication starting from 2015 to 2019, journals in full text form and the study sample is conducted only to nurses in hospitals. The exclusion criteria were published articles not in the form of publications, abstracts only and books. The key is according to the writing title such as Evidence-Based Practice (EBP), Nursing Implementation, Readiness Factors, EBP Leadership, Hospital Barriers, and Facilitators.

Screening from 198 sources of literature to 17 literature based on criteria determined by the author of each journal taken. An overview of the process of searching and reviewing literature can be seen in Figure 1 below.

The main focus of this literature review was the support of coworkers and nurse managers in EBP implementation. The results of the review are presented in the form of a narrative table consisting of researchers and years, titles, objectives, research design and result

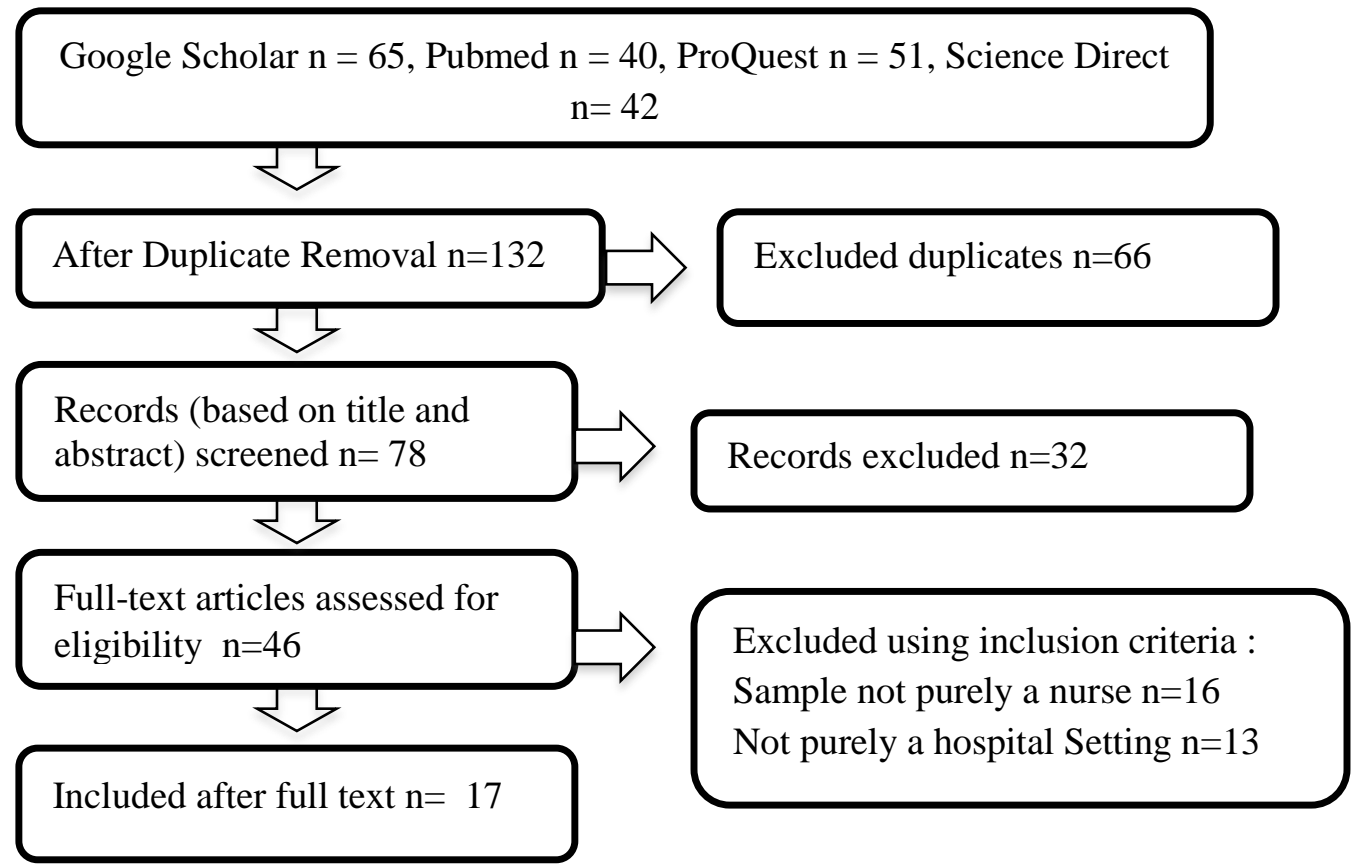

Figure 1. Overview of the Process of Searching and Reviewing Literature 
Tabel 1. Result of the Included Studies

\begin{tabular}{|c|c|c|c|c|}
\hline No & Author (Year) & Research Title & $\begin{array}{l}\text { Design } \\
\text { Research }\end{array}$ & Result \\
\hline 1 & $\begin{array}{l}\text { Yoo, J. Y., Kim, J. } \\
\text { H., Kim, J. S., Kim, } \\
\text { H. L., \& Ki, J. S. } \\
(2019) .\end{array}$ & $\begin{array}{lr}\text { Clinical nurses' } & \text { beliefs, } \\
\text { knowledge, } & \\
\text { organizational readiness } \\
\text { and level of } \\
\text { implementation } \\
\text { evidence-based practice: } \\
\text { The first step to creating } \\
\text { an evidence-based } \\
\text { practice culture }\end{array}$ & $\begin{array}{l}\text { cross- } \\
\text { sectional }\end{array}$ & $\begin{array}{l}\text { - Low share of EBP ideas and } \\
\text { information with work colleagues } \\
-\quad \text { The lack of authority of clinical } \\
\text { nurses in changing practices }\end{array}$ \\
\hline 2 & 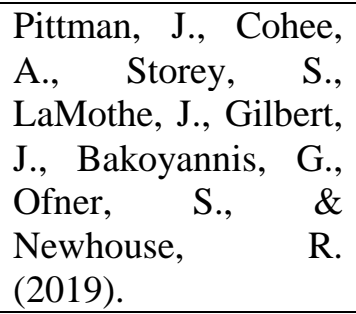 & $\begin{array}{l}\text { A Multisite Health } \\
\text { System Survey to Assess } \\
\text { Organizational Context to } \\
\text { Support Evidence- Based } \\
\text { Practice }\end{array}$ & $\begin{array}{l}\text { cross- } \\
\text { sectional }\end{array}$ & $\begin{array}{l}\text { - Clinical nurses felt less supportive } \\
\text { for nursing managers in EBP } \\
\text { culture } \\
\text { - Clinical nurses had low clinical } \\
\text { decision-making authority }\end{array}$ \\
\hline 3 & $\begin{array}{l}\text { Chen, L., Wu, Y., } \\
\text { Zhou, C., Li, X., \& } \\
\text { Zhao, H. (2019). }\end{array}$ & $\begin{array}{l}\text { Value, Knowledge, and } \\
\text { Implementation on } \\
\text { Evidence-based practice } \\
\text { among nurse managers in } \\
\text { China: a regional cross- } \\
\text { sectional survey }\end{array}$ & $\begin{array}{l}\text { cross- } \\
\text { sectional }\end{array}$ & $\begin{array}{l}\text { - Nurse managers had low } \\
\text { knowledge of EB } \\
\text { - The nurse manager had a } \\
\text { relatively positive attitude about } \\
\text { EBP. } \\
\text { - The implementation of EBP in } \\
\text { nurse managers had been poor in } \\
\text { the last } 12 \text { months }\end{array}$ \\
\hline 4 & $\begin{array}{l}\text { Shuman, C. J., } \\
\text { Powers, } \quad \text { K., } \\
\text { Banaszak-Holl, J., \& } \\
\text { Titler, M. G. (2019). }\end{array}$ & $\begin{array}{l}\text { Unit Leadership and } \\
\text { Climates for Evidence- } \\
\text { Based Practice } \\
\text { Implementation in Acute } \\
\text { Care: A Cross-Sectional } \\
\text { Descriptive Study }\end{array}$ & $\begin{array}{l}\text { Cross- } \\
\text { Sectional }\end{array}$ & $\begin{array}{l}\text { - High competence in the nursing } \\
\text { manager, EBP subscale } \\
\text { Knowledge and EBP Activity } \\
\text { - Proactive leadership in EBP } \\
\text { showed low meant scores on } \\
\text { nursing staff and nursing } \\
\text { managers }\end{array}$ \\
\hline 5 & $\begin{array}{l}\text { Gifford, W., Zhang, } \\
\text { Q., Chen, S., Davies, } \\
\text { B., Xie, R., Wen, S. } \\
\text { W., \& Harvey, G. } \\
(2018)\end{array}$ & $\begin{array}{l}\text { When east meets west: A } \\
\text { qualitative study of } \\
\text { barriers and facilitators to } \\
\text { evidence-based practice } \\
\text { in Hunan China }\end{array}$ & $\begin{array}{l}\text { qualitative, e } \\
\text { xplore the } \\
\text { experiences } \\
\text { of a } \\
\text { phenomenon }\end{array}$ & $\begin{array}{l}\text { Lack of leadership support, } \\
-\quad \text { Lack of understanding and } \\
\text { commitment by senior leaders to } \\
\text { EBP implementation } \\
-\quad \text { It was necessary to have an EBP } \\
\text { team present }\end{array}$ \\
\hline
\end{tabular}




\begin{tabular}{|c|c|c|c|c|}
\hline 6 & $\begin{array}{l}\text { Farokhzadian, J., } \\
\text { Nayeri, N., Borhani, } \\
\text { F., \& Zare, M. } \\
(2015) . \mathrm{N}\end{array}$ & $\begin{array}{l}\text { Nurse leaders' Attitudes, } \\
\text { Self-Efficacy and training } \\
\text { Needs for Implementing } \\
\text { Evidence-Based Practice: } \\
\text { Is It Time for a Change } \\
\text { toward Safe Care? }\end{array}$ & $\begin{array}{l}\text { cross- } \\
\text { sectional }\end{array}$ & $\begin{array}{l}\text { - Iranian nurse leaders used a task- } \\
\text { based approach, because of their } \\
\text { low self-efficacy to integrate EBP } \\
\text { into their practice and their } \\
\text { attitude towards EBP is not good. } \\
-\quad 60 \% \text { of nurse leaders believed that } \\
\text { research activities should not be } \\
\text { considered in evaluating nurse } \\
\text { performance and promotion } \\
\text { indicators to senior positions. }\end{array}$ \\
\hline 7 & $\begin{array}{l}\text { van der Goot, W. E., } \\
\text { Keers, J. C., Kuipers, } \\
\text { R., Nieweg, R. M. } \\
\text { B., \& de Groot, M. } \\
(2018) \text {. }\end{array}$ & $\begin{array}{l}\text { The effect of a } \\
\text { multifaceted } \\
\text { based } \\
\text { programme for nurses on } \\
\text { practice } \\
\text { knowledge, } \\
\text { attitudes, and perceived } \\
\text { barriers: A cohort study }\end{array}$ & $\begin{array}{l}\text { multiple- } \\
\text { cohort study }\end{array}$ & $\begin{array}{l}\text { - the attitude of colleagues who did } \\
\text { not support EBP } \\
\text { - } \text { the nurse believed that she does } \\
\text { not have sufficient authority to } \\
\text { change patient care procedures }\end{array}$ \\
\hline 8 & $\begin{array}{l}\text { Shuman, C. J., Liu, } \\
\text { X., Aebersold, M. L., } \\
\text { Tschannen, D., } \\
\text { Banaszak-Holl, J., \& } \\
\text { Titler, M. G. (2018). }\end{array}$ & $\begin{array}{l}\text { Associations among unit } \\
\text { leadership and unit } \\
\text { climates } \\
\text { implementation in acute } \\
\text { care: a cross-sectional } \\
\text { study }\end{array}$ & $\begin{array}{l}\text { cross- } \\
\text { sectional }\end{array}$ & $\begin{array}{l}\text { Nurse managers were not } \\
\text { confident in implementing EBP }\end{array}$ \\
\hline 9 & $\begin{array}{l}\text { Saunders, H., \& } \\
\text { Vehviläinen- } \\
\text { Julkunen, K. (2017). }\end{array}$ & $\begin{array}{l}\text { Nurses' Evidence-Based } \\
\text { Practice Beliefs and the } \\
\text { Role of Evidence-Based } \\
\text { Practice Mentors at } \\
\text { University Hospitals in } \\
\text { Finland }\end{array}$ & $\begin{array}{l}\text { cross- } \\
\text { sectional }\end{array}$ & $\begin{array}{l}\text { - The manager or administrator of } \\
\text { the RN has significantly more } \\
\text { confidence than the RN clinical, } \\
\text { but statistically there was no } \\
\text { significant difference } \\
\text { - Specialist nurse and clinical nurse } \\
\text { teachers are EBP mentors with the } \\
\text { best competence }\end{array}$ \\
\hline 10 & $\begin{array}{l}\text { Harper, M. G., } \\
\text { Gallagher-Ford, L., } \\
\text { Warren, J. I., } \\
\text { Troseth, M., Sinnott, } \\
\text { L. T., \& Thomas, B. } \\
\text { K. (2017). }\end{array}$ & $\begin{array}{l}\text { Evidence-Based Practice } \\
\text { and U.S. Healthcare } \\
\text { Outcomes: Findings from } \\
\text { a National Survey with } \\
\text { Nursing Professional } \\
\text { Development } \\
\text { Practitioners }\end{array}$ & $\begin{array}{l}\text { cross- } \\
\text { sectional }\end{array}$ & 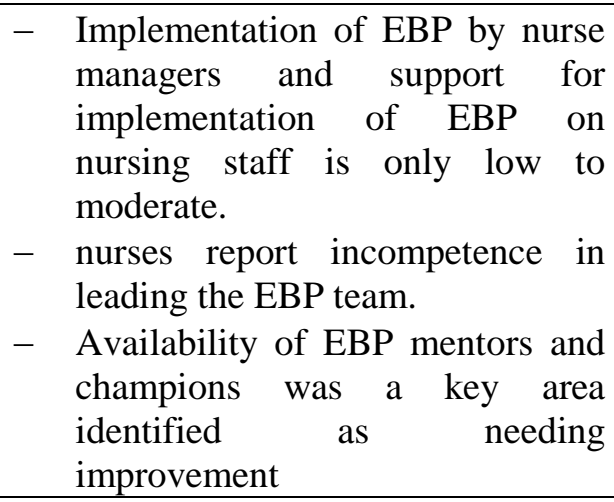 \\
\hline 11 & $\begin{array}{l}\text { Hamaideh, S. H. } \\
\text { (2017). }\end{array}$ & $\begin{array}{l}\text { Sources of Knowledge } \\
\text { and Barriers of } \\
\text { Implementing Evidence- } \\
\text { Based Practice Among } \\
\text { Mental Health Nurses in } \\
\text { Saudi Arabia }\end{array}$ & & $\begin{array}{l}\text { - Lack of nurse authority in } \\
\text { changing practices } \\
\text { - Low support from colleagues in } \\
\text { changing EBP-based practices }\end{array}$ \\
\hline
\end{tabular}




\begin{tabular}{|c|c|c|c|c|}
\hline 12 & $\begin{array}{l}\text { Stavor, D. C., } \\
\text { Zedreck-Gonzalez, } \\
\text { J., \& Hoffmann, R. } \\
\text { L. (2017). }\end{array}$ & $\begin{array}{l}\text { Improving the Use of } \\
\text { Evidence-Based Practice } \\
\text { and Research Utilization } \\
\text { Through the } \\
\text { Identification of Barriers } \\
\text { to Implementation in a } \\
\text { Critical Access Hospital }\end{array}$ & $\begin{array}{l}\text { cross- } \\
\text { sectional }\end{array}$ & 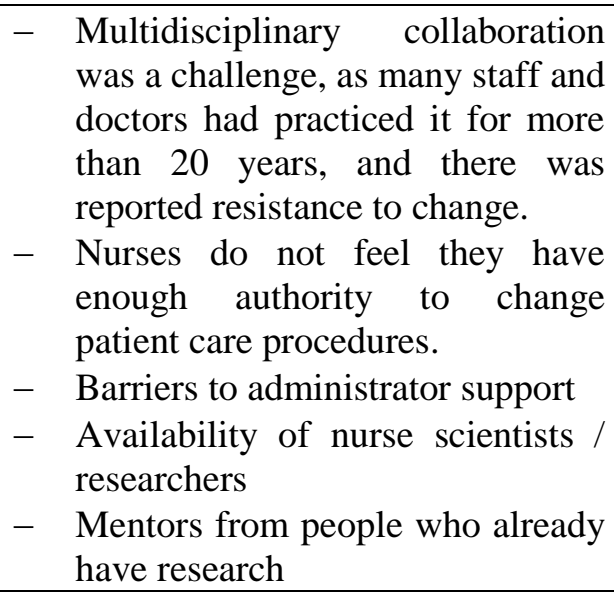 \\
\hline 13 & $\begin{array}{l}\text { Nguyen, T. N. M., \& } \\
\text { Wilson, A. (2016). }\end{array}$ & $\begin{array}{l}\text { Hospital readiness for } \\
\text { undertaking evidence- } \\
\text { based practice: A survey }\end{array}$ & $\begin{array}{l}\text { cross- } \\
\text { sectional }\end{array}$ & 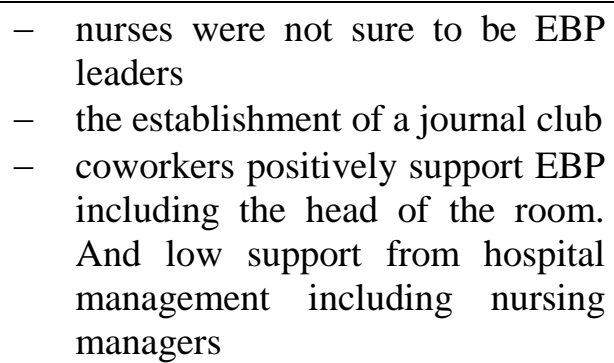 \\
\hline 14 & 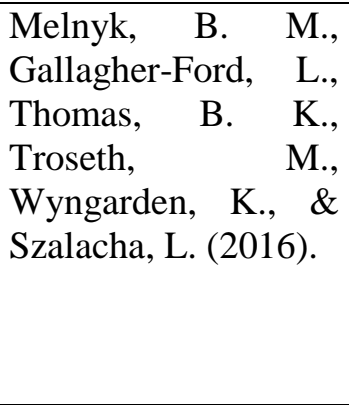 & $\begin{array}{l}\text { A Study of Chief Nurse } \\
\text { Executives Indicates Low } \\
\text { Prioritization of } \\
\text { Evidence-Based Practice } \\
\text { and Shortcomings in } \\
\text { Hospital Performance } \\
\text { Metrics Across the United } \\
\text { States }\end{array}$ & $\begin{array}{l}\text { cross- } \\
\text { sectiona }\end{array}$ & $\begin{array}{l}\text { - Nearly } 60 \% \text { of nursing ward } \\
\text { heads report that they believe in } \\
\text { EBP. } \\
\text { - The head nurse prioritizes primary } \\
\text { care quality and safety, only } 3 \% \\
\text { of the head nurses mentioned EBP } \\
\text { as a top priority. In fact, EBP can } \\
\text { improve the quality and safety of } \\
\text { care }\end{array}$ \\
\hline 15 & $\begin{array}{l}\text { Jordan, P., Bowers, } \\
\text { C., \& Morton, D. } \\
(2016) .\end{array}$ & $\begin{array}{l}\text { Barriers to implementing } \\
\text { evidence-based practice } \\
\text { in a private intensive care } \\
\text { unit in the Eastern Cape }\end{array}$ & $\begin{array}{l}\text { quantitativee } \\
\text { xploratory } \\
\text { research }\end{array}$ & 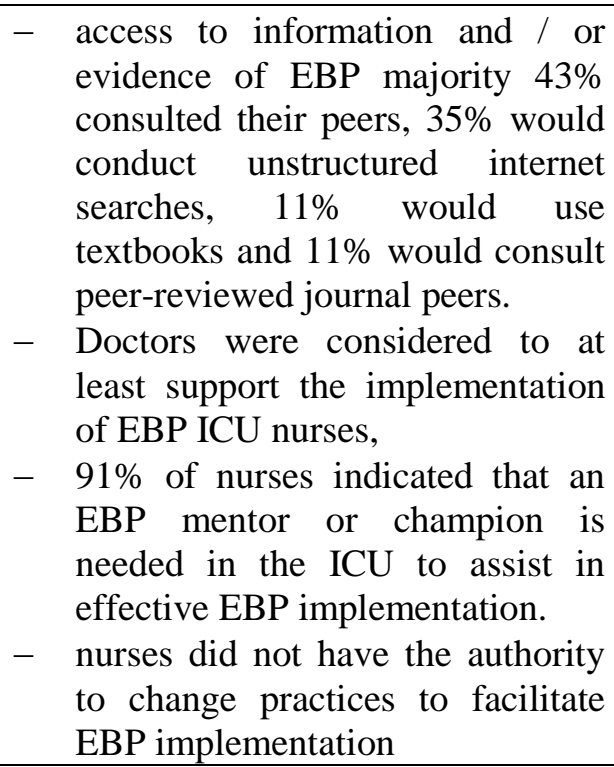 \\
\hline
\end{tabular}




\begin{tabular}{|l|l|l|l|l|}
\hline 16 & $\begin{array}{l}\text { Malik, G., McKenna, } \\
\text { L., \& Plummer, V. } \\
\text { (2016). }\end{array}$ & $\begin{array}{l}\text { Facilitators and barriers to } \\
\text { evidence-based practice: } \\
\text { perceptions of nurse } \\
\text { educators, } \\
\text { coaches and nurse } \\
\text { specialists from a } \\
\text { descriptive study }\end{array}$ & $\begin{array}{l}\text { cross- } \\
\text { sectional }\end{array}$ & $\begin{array}{l}\text { The highest support in the } \\
\text { implementation of EBP come } \\
\text { from nursing partners }\end{array}$ \\
\hline 17 & Hadgu, G. (2015). & $\begin{array}{l}\text { Assessment of Nurses' } \\
\text { Perceptions and Barriers } \\
\text { on Evidence Based } \\
\text { Practice in Tikur Anbessa } \\
\text { Specialized Hospital } \\
\text { Addis Ababa Ethiopia }\end{array}$ & $\begin{array}{l}\text { cross- } \\
\text { sectional }\end{array}$ & $-\begin{array}{l}\text { lack of the EBP model } \\
\text { significant relationship with EBP } \\
\text { implementation }\end{array}$ \\
\hline
\end{tabular}

\section{Results and Discussion}

Among these, the 17 journals included in this literature review shows the characteristics of similar results in which 8 journals concluded that at the care unit level the factors influenced by colleague support and authority in changing practices influence the implementation of EBP (Hamaideh, 2017; Jordan et al., 2016; Malik et al., 2016; Nguyen \& Wilson, 2016; Pittman et al., 2019; Stavor et al., 2017; van der Goot et al., 2018; Yoo et al., 2019). By referring to thirteen journals concluded that nursing leaders influenced the implementation of EBP consisting of leadership support and mentorship including less knowledge and skills than nursing leaders would EBP (Chen et al., 2019; Gifford et al., 2018; Hadgu, 2015; Harper et al., 2017; Jordan et al., 2016; Melnyk et al., 2016; Pittman et al., 2019; Saunders et al., 2017; Shuman et al., 2018, 2019; Stavor et al., 2017; van der Goot et. al., 2018; Yoo et al., 2019)

\section{EBP at the Maintenance Unit Level}

In accord with the analysis shown in table I, there are five journals stating that the support factors of nurse colleagues influence the implementation of EBP (Hamaideh, 2017; Malik et al., 2016; Nguyen \& Wilson, 2016; van der Goot et al., 2018; Yoo et al., 2016; al., 2019). Three studies mention the low support in the form of lack of sharing ideas or information on EBP in the South Korea study, the attitude of low nurse colleagues in studies in the Netherlands and support in changing EBP practices in the United States (Hamaideh, 2017; van der Goot et al., 2018; Yoo et al., 2019). Two other studies in Australia and Vietnam stated that the highest support came from fellow nurses (Malik et al., 2016; Nguyen et al., 2016).

The support of colleagues is important in the implementation of EBP because the characteristics of nurses in obtaining information are mainly sourced from coworkers. This is in accordance with the findings of research conducted in South Africa in the ICU unit that the majority of access to information or evidence for EBP comes from consultations with fellow nurses, then second in order to conduct unstructured internet searches and use textbooks (Jordan et al., 2016).

Doctors as co-workers have different influences on nurses' EBP implementation. Two studies concluded that physicians were a barrier to EBP implementation. Stavor et al (2017) conducted a study in the United States that found multidisciplinary collaboration was a challenge because many staff and doctors had practiced for more than 20 years and reported resistance to change whereas Jordan et al (2016) said that doctors were considered the least supportive of implementation. Other research has shown a corresponding pattern of contextual differences in 
judgments that EBP ICU nurse in southern Africa. This affects decision making as a nurse's authority in conducting practice, six studies conclude that nurses feel they have low authority in changing patient care practices (Hamaideh, 2017; Jordan et al., 2016; Pittman et al., 2019; Stavor et al., 2017; van der Goot et al., 2018; Yoo et al., 2019).

\section{The Role of the Managerial Nurse in Implementing Unit-Level EBP}

Nursing manager support has a statistically significant relationship to the implementation of EBP in hospitals (Hadgu, 2015). Even though nurse managers have a positive attitude towards EBP but this does not become the same measure of knowledge. Nurse managers have relatively positive attitudes about EBP but have low knowledge, which is statistically significant at the level of nurse manager education where undergraduate education or higher has better EBP value, knowledge, and implementation (Chen et al., 2019).

The high support for EBP was expressed by Nguyen et al (2016) from the head of the room and in Australia by Malik et al (2016) said management was the highest supporter. Shuman et al (2019) et al found that the nurse's EBP ability was high and was supported by Saunders (2017) although it was not statistically significant when compared with clinical nurse knowledge. Additionally, three studies in the United States and one in China stated the lack of support nursing managers receive by clinical nurses in implementing EBP (Gifford et al., 2018; Harper et al., 2017; Pittman et al., 2019; Stavor et al., 2017). The commitment of nursing leaders to the implementation of EBP, nurse managers are not confident in implementing EBP, less proactive, low self-efficacy, EBP is not a priority scale for nursing leaders including eliminating research activities and performance assessment and promotion of senior nursing positions (Chen et al., 2019 ; Farokhzadian et al., 2015; Gifford et al., 2018; Melnyk et al., 2016).

With various obstacles in implementing EBP at the unit level, seven studies suggest that nurses need support in implementing EBP. This support is in the form of forming an EBP team, providing mentors or Champions, where the best qualifications are specialist nurses, clinical teaching nurses with EBP expertise and research nurses in hospitals. (Gifford et al., 2018; Hadgu, 2015; Harper et al., 2017; Jordan et al., 2016; Stavor et al., 2017; Yoo et al., 2019).

\section{Conclusion}

Implementation of Evidenced-based practice (EBP) at nurses at the hospital work unit level is strongly influenced by the conditions of the work environment where colleagues can be the best supporters. For which, the knowledge and skills of nurse colleagues in the work unit EBP can be a source of information and support for other nurses in understanding and implementing EBP. Certainty, it is not only fellow nurses, but doctors are very important colleagues in supporting the practice of EBP nurses. The authority of doctors as patient care decision making allows the emergence of conflicts for nurses in changing EBP practices. Moreover, this is the role of nursing managers in synergizing the supporters and barriers to EBP implementation, not only showing a positive attitude towards EBP but having the ability and expertise to implement EBP. Indeed, nursing manager support has a statistically significant relationship to the implementation of EBP in the hospital. In accord with these findings, nursing managers need to be present as role models for nurses in their respective work units. 


\section{References}

Chen, L., Wu, Y., Zhou, C., Li, X., \& Zhao, H. (2019). Value, Knowledge, and Implementation on Evidence-based practice among nurse managers in China: a regional cross-sectional survey. Journal of Nursing Management. https://doi.org/10.1111/jonm.12907

Farokhzadian, J., Nayeri, N., Borhani, F., \& Zare, M. (2015). Nurse leaders' Attitudes, SelfEfficacy and training Needs for Implementing Evidence-Based Practice: Is It Time for a Change toward Safe Care? British Journal of Medicine and Medical Research, 7(8), 662-671. https://doi.org/10.9734/bjmmr/2015/16487

Gifford, W., Zhang, Q., Chen, S., Davies, B., Xie, R., Wen, S. W., \& Harvey, G. (2018). When east meets west: A qualitative study of barriers and facilitators to evidence-based practice in Hunan China. BMC Nursing, 17(1), 1-11. https://doi.org/10.1186/s12912018-0295-x

Hamaideh, S. H. (2017). Sources of Knowledge and Barriers of Implementing Evidence-Based Practice among Mental Health Nurses in Saudi Arabia. Perspectives in Psychiatric Care, 53(3), 190-198. https://doi.org/10.1111/ppc.12156

Harper, M. G., Gallagher-Ford, L., Warren, J. I., Troseth, M., Sinnott, L. T., \& Thomas, B. K. (2017). Evidence-Based Practice and U.S. Healthcare Outcomes: Findings from a National Survey with Nursing Professional Development Practitioners. Journal for Nurses in Professional Development, 33(4), 170-179. https://doi.org/10.1097/NND.0000000000000360

Irmayanti, R. (2019). Persepsi perawat tentang evidence based nursing practice (ebnp) dirumah sakit dr.achmad mochtar bukittinggi. 1-4.

Jordan, P., Bowers, C., \& Morton, D. (2016). Barriers to implementing evidence-based practice in a private intensive care unit in the Eastern Cape. Southern African Journal of Critical Care, 32(2), 50-54. https://doi.org/10.7196/SAJCC.2016.v32i2.253

Melnyk, B. M., Gallagher-Ford, L., Thomas, B. K., Troseth, M., Wyngarden, K., \& Szalacha, L. (2016). A Study of Chief Nurse Executives Indicates Low Prioritization of EvidenceBased Practice and Shortcomings in Hospital Performance Metrics Across the United States. Worldviews on Evidence-Based Nursing, 13(1), 6-14. https://doi.org/10.1111/wvn.12133

Nguyen, T. N. M., \& Wilson, A. (2016). Hospital readiness for undertaking evidence-based practice: A survey. Nursing and Health Sciences, 18(4), 465-472. https://doi.org/10.1111/nhs.12293

Pittman, J., Cohee, A., Storey, S., LaMothe, J., Gilbert, J., Bakoyannis, G., Ofner, S., \& Newhouse, R. (2019). A Multisite Health System Survey to Assess Organizational Context to Support Evidence-Based Practice. Worldviews on Evidence-Based Nursing, 16(4), 271-280. https://doi.org/10.1111/wvn.12375

Saunders, H., \& Vehviläinen-Julkunen, K. (2017). Nurses’ Evidence-Based Practice Beliefs and the Role of Evidence-Based Practice Mentors at University Hospitals in Finland. Worldviews on Evidence-Based Nursing, 14(1), 35-45. https://doi.org/10.1111/wvn.12189 
Shuman, C. J., Liu, X., Aebersold, M. L., Tschannen, D., Banaszak-Holl, J., \& Titler, M. G. (2018). Associations among unit leadership and unit climates for implementation in acute care: a cross-sectional study. Implementation Science: IS, 13(1), 62. https://doi.org/10.1186/s13012-018-0753-6

Shuman, C. J., Powers, K., Banaszak-Holl, J., \& Titler, M. G. (2019). Unit Leadership and Climates for Evidence-Based Practice Implementation in Acute Care: A Cross-Sectional Descriptive Study. Journal of Nursing Scholarship, 51(1), 114-124. https://doi.org/10.1111/jnu.12452

Stavor, D. C., Zedreck-Gonzalez, J., \& Hoffmann, R. L. (2017). Improving the Use of EvidenceBased Practice and Research Utilization Through the Identification of Barriers to Implementation in a Critical Access Hospital. Journal of Nursing Administration, 47(1), 56-61. https://doi.org/10.1097/NNA.0000000000000437

Van der Goot, W. E., Keers, J. C., Kuipers, R., Nieweg, R. M. B., \& de Groot, M. (2018). The effect of a multifaceted evidence-based practice programme for nurses on knowledge, skills, attitudes, and perceived barriers: A cohort study. Nurse Education Today, 63(June 2017), 6-11. https://doi.org/10.1016/j.nedt.2018.01.008

World Health Organization. (2017). Facilitating evidence-based practice in nursing and midwifery in the WHO European Region. WHO.Int, 2-6. http://www.euro.who.int/_data/assets/pdf_file/0017/348020/WH06_EBP_report_comp lete.pdf?ua=1

Yoo, J. Y., Kim, J. H., Kim, J. S., Kim, H. L., \& Ki, J. S. (2019). Clinical nurses' beliefs, knowledge, organizational readiness and level of implementation of evidence-based practice: The first step to creating an evidence-based practice culture. PLoS ONE, 14(12), 1-15. https://doi.org/10.1371/journal.pone.0226742 